\title{
Transformation Through Transformative Education: From an Egg to a New Butterfly
}

\author{
Sikha Gurung* \\ School of Education, Kathmandu University, Lalitpur,Nepal
}

\begin{abstract}
This reflective note is a response to the first international Conference on Transformative Education Research and Sustainable Development that took place in Dhulikhel, Nepal, in October 2016. In this reflective note, I begin by pondering on what makes a novice academic creative and transformative. Then, I deal with the conference atmosphere, contemplate how it connects close to my heart, and finally conclude with my realisation of transformation inside. I particularly reflect on my experiences of being a volunteer to help the scholars from various parts of the world; a rapporteur to witness various talk presentations and report on them; and a participant to attend and learn from some exemplary reports and presentations - all centred at transformative education.
\end{abstract}

Keywords: Reflective Experience; Novice Academic; Academic Conference; Transformative Education

\section{Reflections From a Novice Academic}

For oft when on my couch I lie In vacant or in pensive mood, They flash upon that inward eye Which is the bliss of solitude, And then my heart with pleasure fills,

And dances with the Daffodils.

William Wordsworth (1770-1850)

Life has always been poetic to me; full of metaphors and similes. Most of the times, life is like a roller-coaster ride. To start with, it has lots of ups and downs. We enjoy happiness at good moments, while we also have to face the unpleasant ones. Next, it has twists and turns. We never know what it has to offer us next to its winding streets. Then finally, one day, it ends after it starts. Life begins with birth and ends with death. It does not continue forever. Thus, life is indeed an experience of journey on a ride.

Learning literature for some years has motivated me to see peculiar things in the usual environment around us and get inspired by their uniqueness. Moreover, I enjoy 
experiencing the beauty of an exceptional journey. Thus, one day, the winding street of my life offered me the First International Conference of Transformative Research Education and Sustainable Development (TERSD) in its next turn. What else could have been asked by a novice research scholar than living her theoretical learning on a practical ground? It was in the year 2016 that I had just begun my MPhil in English Language Education at Kathmandu University School of Education (KUSOED). I was trying to understand the basics of research education and know what it meant to write an abstract of an academic paper and present it in front of a scholarly mass. Coincidentally, as we say, right thing happens in the right time, that same year, I got a genuinely favourable and inspiring opportunity to attend the first International Conference on Transformative Education Research and Sustainable Development as a volunteer, a rapporteur and a participant - all at the same time. It was an extraordinary text I had the opportunity to read in the cool month of October of 2016. However, as I reflect on the wonderful experience, I get nostalgic of not so old past memory of my life.

Since last month, I have been pondering what inspires me the most and at all times? What is it? What is it? I thought and thought. I got the idea, cancelled it, and then thought for another. I walked and looked around, I watched, I slept, I woke up and I asked, "A person, or a teacher?" I asked myself. "Yes, it's a person," I replied to my own query. It is someone who is different. "Or is it a painting?" I continued asking. "Oh! Wow, a peculiar one." "Or, perhaps could it be a movie?" I asked again. "Yes, definitely, a differently told story," I replied to myself. That's it. I got the word, "Different". "Is it someone or something different that inspires me?" I continued to ponder. Therefore, when I close my eyes and try to see what different things have inspired me so far? There are many. What comes to me instantly?

Let me start with a memory afresh. It was a few days ago, when I saw and watched and read. I saw an evening sky which was dark but with a light at the centre; I watched a horror movie with a social message; and I read about a writer who says her thoughts inspired her to become a writer, not any other. All of them were so different. I thought to relate them to my life. I got inspired to be creative. They inspired me to continue and end the story that I had been trying to write for a month about a girl who has hair made of gold strands. It is a story of a unique beauty, hope and victory.

Similarly, one day, I saw a man walking zigzag on the road. Everybody looked and laughed at him. He was funny to me as well but different on a closer look and second thought. I asked myself, "Why don't people look at others who are walking straight or in a normal way?" That man had made a significant place in my curious mind. I had treasured it to pour somewhere else. That same week or month, I had to demonstrate a 15 minute class for a job. So, I started pondering on some different ways of doing it to create a longlasting impression. At that moment, the man's incident struck my mind. The next morning, 
72 S. Gurung

I went to the class with that incident in my mind. I opened the door of the class and started walking zigzag inside the class.

I stopped and said, "Good Morning everyone."

The students replied, "Good Morning, ma'am!"

I walked again towards the door and spoke louder this time "Good Morning everyone.'

The students replied, 'Good Morning, ma'am!'

Then, I kept quiet for some time.

One of the students raised his hand and asked, "Ma'am, why did you enter the class that way?"

I smiled and said, "You tell me. Why do you think I did so? What does it tell you about me?"

One of them said, "You are funny."

Another said, "It was unique."

Yet, another uttered, "You are different."

By the time, most of them put forth their opinions, the students and I were almost comfortable with each other. It helped me to further the class on the topic of creating an impression through uniqueness.

Next, I remember, one afternoon I was terribly upset. I was upset because of my stupid and indifferent behaviour toward one of my mentors. I had upset him badly. I behaved normally with people outside, I exchanged with them the usual smile, but from inside I felt like running into the washroom and giving out a loud cry. But I laughed loud trying to suppress the loudness of my guilty emotions. Just then a flower, different one, which had many petals, attracted me. I went closer and took its picture. I felt better. In the evening, at home I sat down to write something for my mentor on the social networking site to apologise for my mistake taking the opportunity of one of his achievements. I wrote:

Dear Sir, I saw this flower blooming in the premises of KUSOED and took a picture to capture its beauty. Later, on a closer look, I saw it had many petals: fully, partially or in the process of blooming. So, when I was thinking of congratulating and thanking you in a different way for whatever you have done for so many students like us, I could actually see in this flower, a teacher like you who has inspired so many of us to grow and bloom.

Now, while reflecting on the text that I had read in 2016, the theme of the conference, "Transformative Education, Research and Development for Sustainable Future" enhanced by its welcoming venue in Dhulikhel, grabbed my immediate expectation that something interesting was going to be served. The poetic experience had begun. First of all, Dhulikhel activated in me the beautiful memory of my hometown Darjeeling, particularly, its mountainous surrounding and misty sky. It is a small yet beautiful town located at the 
Eastern edge of Kathmandu Valley and on the south of the Himalayas at $1550 \mathrm{~m}$ above the sea level. Mainly known for its mesmerizing scenic beauty, green and lush forests, fresh drinking water and mountains, gave me nostalgia of my childhood memories that I cherish the most in my life. Secondly, the academic environment of Dhulikhel where they have some popular institutions like Kathmandu University, Kathmandu University High School, Dhulikhel Teaching Hospital, etc., is also something my hometown shares in common with it. I thought, it was a perfect combination for an innovation to take place in the field of education and development.

Nevertheless, the most obvious thing was that the diverse lens of transformative education made me feel the transformation inside me from the experiences of being a volunteer to help the scholars from various parts of the world; a rapporteur to witness various talk presentations and report on them; and a participant to attend and learn from some exemplary plenary speeches, poster presentations, workshops, music and socialization; all centred at transformative education. That moment, I felt like being served with a big plate, full of nutritious food helping me gradually transform from an egg to a new butterfly that would eventually learn to fly. The knowledge of research education which was getting sharpened at KUSOED, had gotten a concrete platform. I got inspired to think differently and creatively. I wanted to apply the experience somewhere. Everything was so fresh in my mind. After a few months, I wrote an abstract entitled, "English Teachers of Nepal: Butterflies with Colourful Wings" and got selected as a Creativity Group Scholarship Winner to attend and present a paper at the International Conference for Teachers of English as a Foreign Language (IATEFL) Conference, 2018, Brighton, UK. Hence, while I contemplate on the experience of the whole journey of TERSD, I flutter like a butterfly and my heart with pleasure fills and dances like the heart of Wordsworth with the Daffodils. Life is indeed very poetic; full of metaphors and similes. 